\title{
Kombinasi Klorokuin dan N-Acetyl cysteine Menurunkan Ekspresi iNOS Tubulus Proksimal Ginjal Mencit yang Diinfeksi Plasmodium berghei
}

\section{Chloroqoine and N-Acetyl cysteine Combination Decreased iNOS of Rat Renal Proximal Tubule infected by Plasmodium berghei}

\author{
LEnggar Fitri ${ }^{1}$, Imam Sarwono ${ }^{2}$, Rita Rahmalia ${ }^{3}$ \\ ${ }^{1}$ Laboratorium Parasitologi Fakultas Kedokteran Universitas Brawijaya Malang \\ ${ }^{2}$ Laboratorium Patologi Anatomi Fakultas Kedokteran Universitas Brawijaya Malang \\ ${ }^{3}$ Program Studi Pendidikan Dokter Fakultas Kedokteran Universitas Brawijaya Malang
}

\begin{abstract}
ABSTRAK
Gagal ginjal adalah salah satu komplikasi malaria dengan adanya kerusakan pada tubulus yang selain disebabkan sumbatan kapiler oleh eritrosit terinfeksi Plasmodium juga adanya keterlibatan peningkatan produksi Nitric Oxide yang dikatalis enzim inducible Nitric Oxide Synthase (iNOS). Diharapkan penggunaan kombinasi klorokuin sebagai antimalaria dan $N$-acetyl cysteine (NAC) sebagai antioksidan untuk mencegah terjadinya kerusakan lanjut terutama pada ginjal. Penelitian ini bertujuan untuk mengetahui efek pemberian kombinasi klorokuin dan NAC terhadap ekspresi inducible Nitric Oxide Synthase (iNOS) pada sel tubulus proksimal ginjal terinfeksi malaria. Kombinasi klorokuin dan NAC telah dicobakan pada penelitian ini dengan menggunakan metode penelitian eksperimental terhadap mencit Balb/c jantan yang diinfeksi Plasmodium berghei. Kelompok penelitian dibagi menjadi kelompok kontrol (-) (normal), kelompok kontrol (+) (mencit terinfeksi Plasmodium tanpa terapi), kelompok klorokuin dengan dosis 0,05 mg/grBB, dan kelompok kombinasi klorokuin dengan dosis $0,05 \mathrm{mg} / \mathrm{grBB}$ dan NAC dengan dosis $0,05 \mathrm{mg} / \mathrm{grBB}$. Setelah diinfeksi dan derajat parasitemia mencapai $15 \%$ masing-masing kelompok diberi perlakuan. Pada hari ke 3 dan 7 mencit dari masing-masing kelompok dimatikan. Efek kerja klorokuin dan NAC dilihat dari perubahan jumlah ekspresi iNOS yang dideteksi dengan tehnik imunohistokimia pada sel tubulus proksimal ginjal. Hasil penelitian memperlihatkan bahwa ekspresi iNOS meningkat secara signifikan pada sel tubulus proksimal ginjal yang diinfeksi Plasmodium $(p<0,05)$ dan mengalami penurunan secara signifikan dengan pemberian kombinasi klorokuin dan NAC pada hari ke-3 dan ke-7 $(p<0,05)$. Kesimpulannya pada infeksi Plasmodium ekspresi iNOS pada sel tubulus proksimal ginjal mencit meningkat, ekspresi iNOS menurun baik dengan pemberian klorokuin saja maupun dengan pemberian kombinasi klorokuin dan NAC.
\end{abstract}

Kata Kunci: Plasmodium berghei, klorokuin, $\mathrm{N}$-acetyl cysteine (NAC), inducible Nitric Oxide Synthase (iNOS)

\begin{abstract}
Renal failure is one of malaria complication with the existence tubules cells damage which not only because of the capillary obstruction by Parasitized Red Blood Cells but also by the role of the increasing Nitric Oxide production which catalyzed by inducible Nitric Oxide Synthase (iNOS) enzyme. It is expected that the usage of chloroquine combined with N-acetyl cysteine as antioxidant can prevent further damage of tubules cells. The aim of this research was to investigate the effect of chloroquine combined with NAC on iNOS expression on proximal tubules cells of kidney with malaria infection. Combination of chloroquine and NAC has been tested using experimental research method in male Balb/c mice which was infected by Plasmodium berghei. Research groups were divided to group of normal mice (without infection), group of infected mice without treatment (control group), group of chloroquine with dose $0,05 \mathrm{mg} / \mathrm{grBW}$, group of combination of chloroquine with dose $0,05 \mathrm{mg} / \mathrm{grBW}$ and NAC with dose $0,05 \mathrm{mg} / \mathrm{grBW}$. Treatment was given to each group after infected and the parasitemia degree reached $15 \%$. On the $3^{\text {rd }}$ and $7^{\text {th }}$ day mice from each group was executed. The effect of chloroquine and NAC were observed from the amount of iNOS expression changes which was detected by immunohistochemical staining on proximal tubules cells of kidney. The result of this research showed that iNOS expression increased significantly on proximal tubules cells of kidney infected by Plasmodium berghei and decreased significantly by the treatment of combination of chloroquine and NAC both $3^{\text {td }}$ and $7^{\text {th }}$ day. In conclusion, on Plasmodium infection, the expression of iNOS on proximal tubules cells of kidney increased, and the iNOS expression decreased by the treatment of either by chloroquine alone or by chloroquine combined with NAC.
\end{abstract}

Keywords: Plasmodium berghei, chloroquine, N-acetyl cysteine (NAC), inducible Nitric Oxide Synthase (iNOS) 


\section{PENDAHULUAN}

Malaria merupakan penyakit infeksi yang terjadi hampir di seluruh daerah tropis di dunia. Sekitar 103 negara terinfeksi malaria dan menimbulkan masalah serius bagi negara-negara berkembang. Diperkirakan malaria menyebabkan 300-500 juta kasus per tahun dengan 1,52,7 juta kematian per tahun di dunia (1). Di Indonesia WHO memperkirakan, terdapat 6 juta kasus malaria yang menerima pengobatan dan 700 diantaranya mengalami kematian setiap tahunnya. Malaria juga merupakan penyakit tertinggi keempat yang terjadi pada anak-anak (2).

Terdapat 4 spesies Plasmodium yang menyebabkan malaria yaitu Plasmodium vivax, Plasmodium malariae, Plasmodium ovale, dan Plasmodium falciparum. Dari keempat spesies tersebut diatas, Plasmodium falciparum adalah yang terbanyak menyebabkan kematian karena komplikasi yang ditimbulkan (1).

Keberadaan Plasmodium dalam tubuh akan merangsang sistem imun terutama Reticulo Endothelial System (RES) dengan mengaktivasi sel limfosit $\mathrm{T}$, makrofag, dan berbagai sitokin seperti Tumor Necrosis Factor alpha (TNF $\alpha$ ) dan Interleukin-1 (IL-1), menyebabkan terjadinya induksi pelepasan metabolit oksigen Reactive Oxygen Intermediate (ROI) dan Reactive Nitrogen Intermediate (RNI) yang akan bereaksi membentuk Nitric Oxide (NO) melalui aktivasi inducible Nitric Oxide Synthase (iNOS/NOS $/$ NOS tipe2) yang sebenarnya berperan dalam mengeliminasi parasit, namun karena sifatnya yang tidak spesifik, dapat menyebabkan kelainan patologis (3).

Tingginya kadar Reactive Nitrogen Intermediate (RNI) akan mencetuskan rangsangan terhadap iNOS dan terjadi sintesis NO 100-1000 kali lebih banyak dibanding hasil sintesis NO oleh isoform NOS lainnya seperti endothelial NOS ataupun neuronal NOS. Peningkatan jumlah NO yang terlalu banyak akan mengakibatkan kerusakan oksidatif melalui hambatan respirasi sel sehingga menjadi salah satu penyebab terjadinya komplikasi pada penderita malaria (4).

Gagal ginjal merupakan salah satu komplikasi akibat malaria berat disamping malaria serebral, gangguan hepar, edema paru, dan kelainan lainnya. Mortalitas dapat mencapai $45 \%$ pada malaria berat dengan gangguan fungsi ginjal dibanding dengan yang tanpa kelainan fungsi ginjal yaitu sebesar $10 \%$. Kelainan fungsi ginjal $5-10 \%$ disebabkan nekrosis tubular akut. Nekrosis tubular akut ini disebabkan adanya anoksia karena penurunan aliran darah ginjal sebagai akibat dari sumbatan kapiler (iskemik). Sumbatan tersebut terjadi karena PRBC sulit melalui kapiler karena proses sitoadherensi dan sekuestrasinya. Lokasi tersering dari nekrosis tubular akut akibat malaria adalah segmen proksimal dan lesi primernya adalah sel epitel (5).

Mekanisme lain yang mungkin terlibat pada gagal ginjal adalah dihasilkannya radikal bebas NO yang dikatalis enzim iNOS secara berlebihan yang menyebabkan kerusakan sel ginjal dan gangguan pada fungsi ginjal itu sendiri (6). Suatu penelitian di Thailand berhasil membuktikan adanya ekspresi iNOS pada sel mesangial, sel epitel glomerulus dan tubulus, sel mononuclear, sel endotel dan otot polos pembuluh darah pada jaringan ginjal dari penderita malaria yang meninggal akibat komplikasi (7).

Klorokuin merupakan obat antimalaria yang murah, cukup aman, dan memiliki toksisitas yang rendah. Peran dari klorokuin yaitu sebagai skizontosida darah dengan mekanisme kerja utamanya adalah menghalangi pembentukan hemozoin dari heme yang merupakan hasil pencernaan hemoglobin oleh Plasmodium (8). Heme bebas itu sendiri mampu memicu reaksi pembentukan Reactive Oxygen Species (ROS) yang akan membantu eliminasi Plasmodium dalam eritrosit. Akan tetapi, dalam jumlah berlebihan ROS akan menimbulkan kerusakan sel (9).

Dengan adanya keterlibatan radikal bebas pada patologi penyakit malaria maka perlu ada pemikiran penggunaan terapi antioksidan sebagai terapi suportif dalam proses penyembuhan malaria. Pengobatan malaria yang dikombinasikan dengan antioksidan mulai banyak dikembangkan. Berdasarkan penelitian yang telah dilakukan oleh Fitri et al dilaporkan bahwa terdapat penurunan derajat parasitemia dan peningkatan aktifitas makrofag pada mencit yang diinfeksi $P$. berghei yang telah diterapi kombinasi klorokuin dan vitamin C sebagai antioksidan (10). Penelitian dengan menggunakan kombinasi klorokuin dan $\mathrm{N}$-acetyl cysteine (NAC) sebagai antioksidan juga mulai banyak dilakukan. Salah satunya telah dilaporkan bahwa kombinasi klorokuin dan NAC diduga bekerja secara sinergis dalam menurunkan derajat nekrosis sel epitel tubulus proksimal ginjal mencit yang diinfeksi P. berghei (11).

Antioksidan NAC dan Vitamin C memiliki kelebihan dan kekurangan dalam aplikasinya. Kelebihan menggunakan vitamin C adalah mudah didapat, murah, mudah larut dalam air, akan tetapi vitamin $\mathrm{C}$ merupakan antioksidan eksogen sehingga harus mendapat pasokan dari luar. Sedangkan untuk NAC walaupun keberadaannya kurang dikenal masyarakat, namun NAC memiliki beberapa kelebihan antara lain keberadaan NAC di dalam darah akan menjadi cysteine yang merupakan antioksidan kuat, antitoksin yang cukup penting serta merupakan substansi yang menunjang sistem imun dan mampu meningkatkan antioksidan lain melalui jalur metabolisme glutathione untuk melindungi sel melawan stres oksidatif (12). Pada infeksi Plasmodium, NAC diduga memiliki efek antiplasmodium karena mekanismenya sebagai proteinase inhibitor yang dapat menstabilkan membran eritrosit sehingga menghambat keluarnya Plasmodium dari eritrosit (13).

Diharapkan dengan pemberian kombinasi klorokuin sebagai antimalaria dan NAC sebagai antioksidan diharapkan akan lebih mempercepat eliminasi Plasmodium sekaligus mengurangi aktivitas iNOS yang meningkat akibat infeksi sehingga kerusakan tubulus ginjal dapat dicegah sedini mungkin agar tidak terjadi gagal ginjal yang mampu mengakibatkan kematian. Penelitian ini dilakukan untuk mengetahui perubahan ekspresi Inducible Nitric Oxide Synthase pada sel tubulus proksimal ginjal mencit Balb/C yang diinfeksi Plasmodium berghei dan mengetahui efek pemberian kombinasi klorokuin dan $\mathrm{N}$ acetyl cysteine terhadap ekspresi Inducible Nitric Oxide Synthase pada sel tubulus proksimal ginjal mencit Balb/C yang diinfeksi Plasmodium berghei.

\section{METODE}

Rancangan penelitian yang digunakan merupakan penelitian eksperimental laboratorik (Post test) dengan alur kerja sebagai berikut: Mencit galur Balb/C umur 6-8 minggu dengan berat 20-25 gram yang dibagi menjadi 
kelompok menjadi 2 kelompok yaitu kelompok perlakuan dan kelommpok normal. Pada kelompok perlakuan dilakukan inokulasi Plasmodium berghei $(1 \times 107$ parasit $0,2 \mathrm{ml}$ darah) hingga derajat parasitemia $15 \%$, kemudian dibagi lagi dalam 3 kelompok, kelompok (a) Kelompok yang hanya diinfeksi Plasmodium berghei, kelompok (b) Kelompok yang diinfeksi Plasmodium berghei + pemberian klorokuin $0,05 \mathrm{mg} / \mathrm{gr} \mathrm{BB}$, dan kelompok (c) Kelompok yang diinfeksi Plasmodium berghei + pemberian klorokuin 0,05 mg/gr BB dan NAC 0,05 $\mathrm{mg} / \mathrm{grBB}$. Baik pada kelompok perlakuan dan kelompok normal pada hari ke 3 dan hari ke 7, tiga mencit dimatikan untuk diambil sampel organ ginjalnya. Lalu sampel dibuat menjadi preparat dengan metode parafin tanpa pewarnaan HE tetapi dilakukan pewarnaan imunohistokimia. Pada sampel kemudian dilakukan penghitungan rerata sel tubulus proksimal yang menunjukan terdapatnya ekspresi iNOS (20 LP per slide dengan perbesaran 1000x) dan dilakukan analis data untuk pengitungan lebih akurat.

Data yang diperoleh dicari rata-rata dan standart deviasinya, kemudian dilakukan analisis dengan program SPSS 10.0 for windows melalui metode One way ANOVA untuk mencari nilai perbedaan rerata yang signifikan antar seluruh kelompok perlakuan. Perbedaan rerata pada masing-masing kelompok dilakukan uji Tukey dalam Post Hoc Test dengan tingkat kepercayaan 0,05.

\section{HASIL}

\section{Hasil Pengamatan Sediaan Imunohistokimia}

Hasil pengamatan sediaan ginjal mencit yang telah dilakukan pewarnaan imunohistokimia dengan perbesaran 1000 kali memperlihatkan ekspresi iNOS pada tubulus proksimal ginjal mencit yang telah diinfeksi $P$. berghei. Tanda panah merah menunjukan ekspresi iNOS tampak berwarna coklat kehitaman pada ekstra dan intra sel. Hasil pengamatan disajikan Gambar 1:
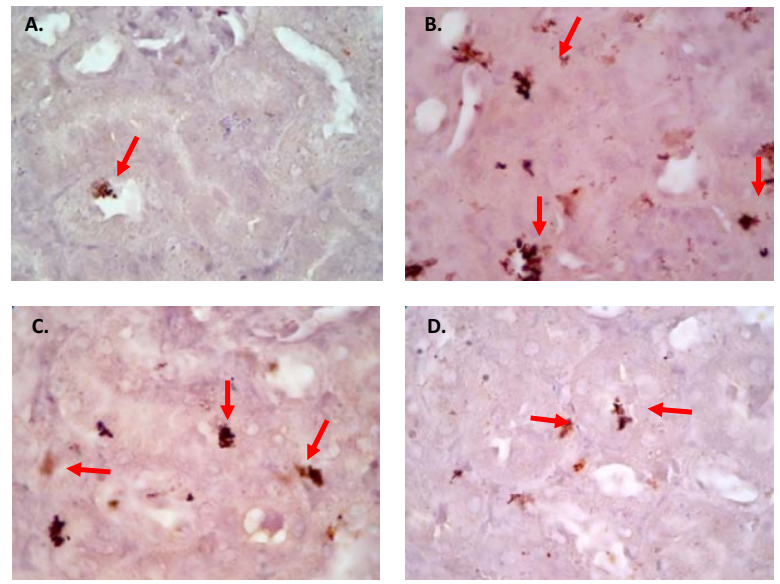

Gambar 2. Hasil pewarnaan imunohistokimia pada sediaan ginjal mencit

Kelompok: A. Kontrol (-); B. Kontrol (+) hari ke-3; C. Klorokuin hari ke-3; D. KN hari ke-3. Ekspresi iNOS pada tubulus proksimal tampak berwarna coklat kehitaman (panah merah) (Perbesaran: 1000x).

\section{Jumlah Eskpresi iNOS}

Parameter yang diukur dalam penelitian ini adalah jumlah ekspresi iNOS pada tubulus proksimal ginjal mencit (Gambar 2).

Hasil pengamatan menunjukkan bahwa ekspresi iNOS lebih tinggi secara bermakna pada infeksi P.berghei dibandingkan normal. Pemberian klorokuin 0,05mg/gr BB tunggal dan kombinasi dengan NAC $0,05 \mathrm{mg} / \mathrm{gr}$ selama 3 dan 7 hari memberikan gambaran jumlah ekspresi yang lebih rendah secara signifikan dibandingkan infeksi $P$. berghei tanpa terapi $(p=0,000)$. Pemberian klorokuin 0.05 $\mathrm{mg} / \mathrm{gr} \mathrm{BB}$ selama tujuh hari memberikan jumlah iNOS yang lebih tinggai secara signifikan dibandingkan pemberian selama tiga hari $(p=0,010)$. Efek penambahan NAC pada terapi klorokuin selama tiga hari dan tujuh hari tidak menunjukkan perbedaan jumlah iNOS yang signifikan $(p=0,215)$. Penambahan NAC pada terapi klorokuin selama tiga hari juga tidak menunjukkan perbedaan jumlah ekspresi iNOS dibandingkan pemberian klorokuin saja selama tiga hari $(p=0,696)$. Penambahan NAC pada terapi klorokuin selama tujuh hari menunjukkan jumlah ekspresi iNOS yang lebih rendah secara signifikan bila dibandingkan klorokuin saja dengan waktu sama $(p=0,000)$.

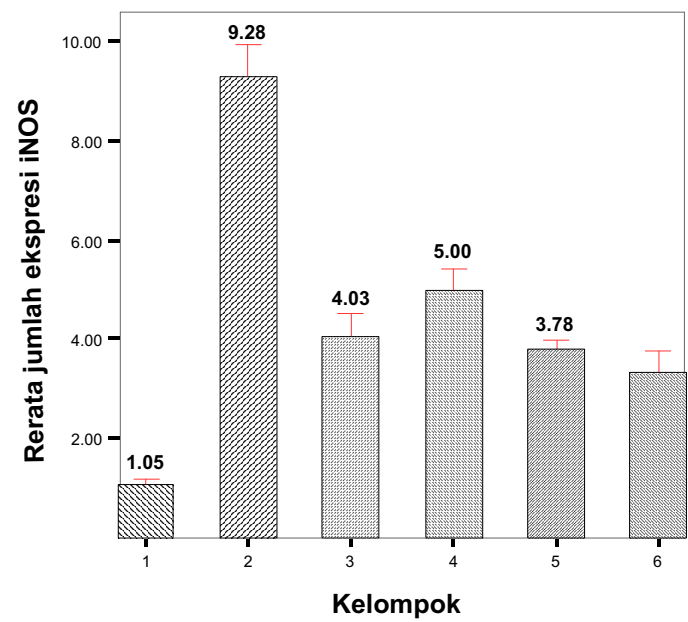

Gambar 1. Gambaran rerata jumlah ekspresi iNOS per lapangan pandang pada tubulus proksimal ginjal mencit

Keterangan:

1. Kelompok mencit tanpa perlakuan (kontrol (-))

2. Kelompok mencit malaria selama 3 hari (kontrol (+) hari ke-3)

3. Kelompok mencit malaria + klorokuin $0,05 \mathrm{mg} / \mathrm{grBB}$ selama 3 hari (klorokuin hari ke-3)

4. Kelompok mencit malaria + klorokuin $0,05 \mathrm{mg} / \mathrm{grBB}$ selama 7 hari (klorokuin hari ke-7)

5. Kelompok mencit malaria + klorokuin 0,05 mg/grBB + NAC 0,05 $\mathrm{mg} / \mathrm{grBB}$ selama 3 hari (KN hari ke-3)

6. Kelompok mencit malaria + klorokuin $0,05 \mathrm{mg} / \mathrm{grBB}+\mathrm{NAC} 0,05$ $\mathrm{mg} / \mathrm{grBB}$ selama 7 hari ( $\mathrm{KN}$ hari ke-7)

\section{DISKUSI}

Komplikasi malaria terjadi akibat adanya gangguan multisistem. Penyakit ini mempunyai gambaran yang luas dan sesuai dengan pola organ yang terkena. Manifestasi malaria berat pada ginjal salah satunya adalah akibat dari sitoadherensi dan sekuestrasi eritrosit yang mengandung parasit pada mikrovaskuler sehingga aliran darah terhambat hingga terjadi hipoksia bahkan anoksia $(5,14)$.

Keberadaan parasit dalam tubuh akan merangsang sistem imun terutama Reticulo Endothelial System (RES) untuk 
melindungi tubuh. Pengenalan parasit yang dalam hal ini sebagai antigen dilakukan oleh Antigen Presenting Cell (APC) yang selanjutnya akan menginduksi aktivitas sel $\mathrm{T}$ Cd4+. Sel T CD4+ yang teraktivasi akan melepaskan berbagai macam sitokin, termasuk diantaranya Interleukin-4 (IL-4) yang berfungsi dalam pelepasan antibodi oleh limfosit-B. Keberadaan antibodi akan membantu dalam proses fagositosis Parasitized Red Blood Cells (PRBC), merozoites bebas atau debris. Sitokin yang lain seperti Interferon gamma (IFN- $\gamma$ ) bisa mengaktivasi sel-sel fagosit, terutama monosit atau makrofag. Makrofag kemudian akan menghasilkan sitokin lain seperti Tumor Necrosis Factor (TNF- $\alpha$ ), IL-6, IL-1, lalu bersama IFN $\gamma$ akan menginduksi makrofag untuk mensintesis Nitric Oxide (NO) melalui reaksi enzimatik Larginin menjadi L-citrulin yang dikatalis oleh inducible Nitric Oxide Syntethase (iNOS/NOS $/$ NOS tipe 2) $(3,15)$.

Nitric Oxide (NO) merupakan suatu radikal bebas berbentuk gas tidak berwarna yang memiliki struktur relatif stabil dan sangat reaktif yang secara normal diproduksi oleh tubuh dalam jumlah yang kecil sebagai suatu zat fisiologis yang menunjang fungsi tubuh serta sebagai pelindung tubuh terhadap serangan agen patogen. Selain membunuh agen patogen NO juga berperan pada kerusakan sel baik sel dari mikroorganisme yang akan dibunuh, sel yang memproduksinya juga sel-sel tetangga (16). Secara fisiologis sintesis NO dikatalis oleh constitutive NOS (neuronal NOS dan endothelial NOS) yang aktivasinya tergantung kadar $\mathrm{Ca}^{2+}$ yang masuk melalui kanal $N$-methyl-D-aspartat (NMDA). Akan tetapi induksi iNOS akan terjadi melalui hipoksia dan sitokin keradangan seperti IL-1, IFN- $\gamma$ dan TNF pada malaria falciparum. Sekali terinduksi, iNOS akan aktif sampai 2436 jam dan memiliki potensi tinggi untuk meningkatkan pembentukan NO patologis oleh karena NO yang dihasilkan menghalangi bentuk fisiologis dengan menghambat masukan $\mathrm{Ca}^{2+}$ melalui umpan balik negatif dari kanal NMDA (14).

Hasil memperlihatkan peningkatan rerata ekspresi iNOS pada tubulus proksimal ginjal mencit yang telah diinfeksi $P$. berghei dibanding kelompok normal. Hal ini berarti infeksi Plasmodium dapat meningkatkan aktivitas iNOS. Secara fisiologis pada sel yang normal ekspresi iNOS terdapat dalam jumlah yang sangat sedikit sekali, namun sekali terbentuk iNOS dapat mensintesis NO 100-1000 kali lebih banyak daripada constitutive NOS (17). Dari penelitian Potup et al bahwa pada jaringan ginjal penderita malaria yang meninggal akibat komplikasi dapat dideteksi adanya ekspresi iNOS pada sel mesangial, epitel glomerulus dan tubulus, mononuclear, endotel dan otot polos pembuluh darah (7).

Pada penelitian ini kelompok kontrol (+) selama 7 hari mencit mati sebelum mencapai hari ke-7. Hal ini bisa diakibatkan semakin tingginya derajat parasitemia. Pada derajat parasitemia lebih dari $15 \%$ mencit banyak yang mati sebelum sempat diterapi obat. Dengan tingginya derajat parasitemia berarti semakin meningkatnya jumlah parasit dalam peredaran darah sehingga mampu menimbulkan komplikasi dan peningkatan radikal bebas yang bersifat toksik terhadap mencit.

Pada pemberian klorokuin sebanyak 0,05 mg/grBB ini tampak terjadi penurunan ekspresi iNOS baik pada hari ke-3 ataupun hari ke-7. Setelah dilakukan uji analisis dengan ANOVA (Tukey) didapatkan perbedaan yang signifikan $(p<0.05)$. Penurunan ekspresi iNOS disebabkan oleh berkurangnya jumlah parasit karena kerja klorokuin sebagai antimalaria dalam mengeliminasi parasit. Beberapa mekanismenya antara lain)menghalangi sintesis asam nukleat dan nukleoprotein dengan menghambat DNA polymerase dan RNA polymerase dari parasit (18) dan menghambat aktivitas enzim heme polymerase sehingga mencegah heme terbentuk menjadi kristal hemozoin. Heme bebas yang meningkat dalam eritrosit mampu mengakibatkan lisis membrane, memicu peningkatan Reactive Oxygen Species (ROS) serta menghambat metabolisme parasit lainnya sehingga heme bebas bersifat toksik terhadap parasit (8). Mekanisme lain penurunan iNOS karena klorokuin dapat menghambat enzim protease parasit yang digunakan untuk mencerna hemoglobin sehingga mengganggu metabolisme parasit (8). Klorokuin saat masuk vakuola makanan parasit dengan sistem transport aktif. Dalam vakuola bersifat asam ini, klorokuin yang bersifat basa lemah bersatu dengan protein menyebabkan alkalinisasi organel. Keadaan ini menyebabkan parasit tidak mampu melakukan digesti (19).

Pemberian klorokuin akan membunuh parasit intraeritrosit mengakibatkan jumlah parasit akan berkurang sehingga akan mencegah terjadinya sitoadherensi yang mampu menimbulkan hipoksia pada parenkim ginjal akibat sumbatan eritrosit yang mengandung parasit serta mengurangi pelepasan sitokin keradangan (5). Hal ini menyebabkan induksi iNOS dalam mensintesis NO juga akan berkurang. Walaupun terjadi penurunan ekspresi iNOS pada pemberian klorokuin dibandingkan dengan kontrol (+), pemberian klorokuin selama 7 hari mengalami peningkatan bila dibandingkan pemberian klorokuin selama 3 hari dengan perbedaan rerata yang signifikan $(p<0,05)$ pada uji analisis ANOVA. Berdasarkan penelitian yang dilakukan Ghigo et al klorokuin mempunyai kemampuan untuk menstimulasi aktivitas enzim NOS pada hewan tikus, babi dan endotel manusia secara invitro. Mekanisme stimulasi ini masih belum diketahui, namun diduga berhubungan dengan kemampuan klorokuin untuk mempengaruhi metabolisme besi (iron) melalui mekanisme lisosomotropik (20).

Heme bebas yang terbentuk akibat penggunaan klorokuin akan memicu reaksi pembentukan ROS yang akan membantu membunuh parasit dalam eritrosit. Akan tetapi, dalam jumlah berlebihan ROS akan menimbulkan kerusakan jaringan akibat radikal bebas yang secara tidak langsung ditingkatkan oleh pemberian klorokuin ini (9). Dalam hubungannya dengan NO, heme merupakan salah satu kofaktor terikat (prostethic group) dari NOS dalam mensintesis NO. Apabila jumlah heme bebas meningkat secara berlebihan maka akan memicu peningkatan sintesis NO yang dikatalis oleh NOS baik oleh inducible NOS ataupun constitutive NOS (8).

Hasil penelitian menunjukkan pemberian kombinasi klorokuin sebanyak $0,05 \mathrm{mg} / \mathrm{grBB}$ dan $\mathrm{N}$-acetyl cysteine (NAC) sebanyak 0,05 mg/grBB, ekspresi iNOS mengalami penurunan baik pada pemberian selama 3 hari ataupun selama 7 hari dibanding dengan kontrol (+) dengan perbedaan yang signifikan. Penurunan ekspresi iNOS juga terjadi pada hari ke-7 bila dibandingkan dengan hari ke-3, akan tetapi pada uji analisis ANOVA perbedaan rerata tidak signifikan.

Penurunan ekspresi iNOS ini selain disebabkan karena 
kerja klorokuin sebagai antimalaria dalam mengeliminasi parasit juga mampu mencegah aktivasi sistem imun dengan menghambat induksi ekspresi gen TNF- $\alpha$ melalui gangguan terhadap lipopolisakarida sehingga menghambat pelepasan sitokin lainnya yang turut berperan dalam menginduksi enzim NOS. Sehingga mengurangi produksi radikal bebas termasuk NO.

Pemberian NAC yang merupakan suatu antioksidan bekerja melalui beberapa mekanisme. Peningkatan glutatione pada pemberian NAC dapat meningkatkan jumlah limfosit CD4+ dan CD8+ sehingga dapat memperkuat dan melindungi sistem imun dalam mengeliminasi parasit yang terdapat di sirkulasi. Glutathione juga terbukti dapat menstabilkan leukosit dan limfosit. Hal ini menyebabkan pelepasan sitokin-sitokin keradangan seperti IL-2 yang bersifat sitotoksik dan dapat memicu kerusakan jaringan dapat ditekan (21). Secara tidak langsung pemberian NAC juga akan menghambat induksi iNOS. N-acetyl cysteine sebagai prekursor glutathione menjadikannya inhibitor kompetitif pada reaksi detoksifikasi heme. Heme yang terbebas sebagai sumber makanan parasit ditangkap oleh glutathione sehingga parasit lebih cepat mati (21). $\mathrm{N}$-acetyl cysteine dalam darah yang kemudian akan diubah menjadi cysteine dapat menimbulkan efek antiplasmodium karena zat ini berfungsi sebagai proteinase inhibitor yang dapat menstabilkan membran eritrosit sehingga menghambat keluarnya Plasmodium dari eritrosit dan mampu menghambat enzim cysteine proteinase yang dibutuhkan oleh plasmodium untuk mendegradasi hemoglobin (13). $\mathrm{N}$-acetyl cysteine diduga mampu menghambat TNF $\alpha$ dan sitoadherensi. TNF $\alpha$ berperan dalam menginduksi sel limfosit dalam pelepasan sitokin keradangan dan bersama IL-1 mampu meningkatkan ekspresi molekul adhesi Intercelluler Adhesin Molecul-1 (ICAM-1) pada proses sitoadherensi. Sitoadherensi merupakan perlekatan antara eritrosit yang mengandung parasit (PRBC) matur pada permukaan endotel vaskuler. Penempelan ini akan menyebabkan penyumbatan kapiler sehingga akan terjadi penurunan aliran darah ke ginjal post sumbatan dan hipoksia ginjal $(5,22)$.

Sitoadherensi yang terjadi pada infeksi malaria

\section{DAFTAR PUSTAKA}

1. Braunwald E, Fauci A, Kasper D, Hauser S, Longo D, and Jameson J. Harrison's Principle of Internal Medicine. 14th edition. New York; McGraw Hill: 2001; p. 1203-1212.

2. Nurul HA. Riset Malaria dan Keanekaragaman Genom Manusia. Medika. 2000; 4

3. Liew FY and Cox FEG. Non Spesific Defence Mechanism: The Role of Nitric Oxide. Immunology Today. 1991; 12(3): 17-21.

4. Kaufmann, S. H. E., 1999, Immunity to Intracellular Bacteria. Annual Review of Immunology. 1993; 11: 129-163.

5. Harijanto PN. Gejala Klinik Malaria Berat. Di dalam: Harijanto PN (ed). Malaria: Epidemiologi, Patogenesis, Manifestasi Klinis dan Penanganannya. Jakarta: EGC; 2000; p: 166-175.

6. Hunt $\mathrm{NH}$, Kopp M, and Stocker R. Free Radicals and menyebabkan peningkatan ekspresi iNOS. Ekspresi ini akan semakin meningkat dengan penambahan TNF $\alpha$ (10). Pelepasan sitokin inflamatori juga mampu menginduksi ekspresi iNOS (14). Dengan penggunaan kombinasi klorokuin dan NAC maka jumlah parasit yang beredar dalam darah akan semakin berkurang sehingga induksi terhadap sitokin inflamatori termasuk TNF $\alpha$ dan proses sitoadherensi pun akan berkurang. Hal ini dapat mengakibatkan terjadinya penurunan ekspresi iNOS. Dapat dilihat pada pemberian perlakuan selama 3 hari, tampak rerata ekspresi iNOS pada kelompok KN lebih sedikit jumlahnya bila dibanding dengan pemberian klorokuin saja, akan tetapi perbedaannya tidak signifikan $(p>0,05)$. Hal yang sama tampak pada pemberian perlakuan selama 7 hari dengan perbedaan yang signifikan $(p<0,05)$

Penggunaan NAC dalam terapi bersama klorokuin juga diharapkan mampu menurunkan radikal bebas ROS berlebih yang pembentukannya secara tidak langsung dipicu oleh peningkatan jumlah heme bebas akibat penggunaan klorokuin (9). N-acetyl cysteine sebagai prekursor glutathione merupakan antioksidan penting yang memiliki fungsi proteksi terhadap sel dalam melawan stres oksidatif dan mampu menangkap heme bebas (12). Sebagai antioksidan pencegah cysteine dapat mencegah timbunan radikal hidroksil $\left(\mathrm{OH}^{*}\right)$ dengan mengkatalisirnya menjadi $\mathrm{H}_{2} \mathrm{O}$ (21). Dengan berkurangnya jumlah ROS yang berlebih maka akan mencegah kerusakan jaringan akibat radikal bebas.

Hasil penelitian ini membuktikan ekspresi inducible Nitric Oxide Synthase meningkat pada sel tubulus proksimal ginjal mencit Balb/c yang diinfeksi Plasmodium berghei. Pemberian klorokuin saja dengan dosis $0,05 \mathrm{mg} / \mathrm{grBB}$ dan kombinasi klorokuin dengan dosis $0,05 \mathrm{mg} / \mathrm{grBB}$ bersama $\mathrm{N}$-acetyl cysteine dengan dosis $0,05 \mathrm{mg} / \mathrm{grBB}$ terbukti dapat mengurangi ekspresi inducible Nitric Oxide Synthase pada sel tubulus proksimal ginjal mencit Balb/c yang diinfeksi Plasmodium berghei baik pada pemberian selama 3 hari maupun 7 hari. Studi lanjut perlu dilakukan untuk melihat efek terpisah NAC sebagai antiplasmodium dan dalam jangka waktu yang lebih lama untuk mengamati fluktuasi ekspresi iNOS.

Antioxidants. In: Ong ASH, Packer (Eds). Lipid Soluble Antioxidant, Biochemistry and Clinical Aplication. Basel: Birkhauser Verlag; 1992; p. 337-354.

7. Potup $P$, Viriyarejakul $P$, Punpoowong $B$, Pongponratn $\mathrm{E}$, Khachansaksumet V, and Maneerat Y. Nitric Oxide Involvment in Pathogenesis of Kidney in Falciparum Malaria. (O $\mathrm{nl}$ i n e ) 2003 . http://www.tm.mahidol.ac.th/tmpt/d_pathology_ab stract_12.htm. [diakses tanggal 18 September 2005].

8. Wiser MF. Chloroquine and the Food Vacuole. (Online) 2003. http://www.tulane.edu / wiser /protozoology/notes/drugs.html. [diakses tanggal 15 Juni 2005].

9. Goldsmith R. Obat Antimalaria. Di dalam: BG Katzung BG (Ed). Farmakologi Dasar dan Klinik edisi 6. Jakarta: EGC; 1997; p. 563-572.

10. Fitri LE. Analisis Patogenesis Malaria dengan Komplikasi: Tinjauan Molekuler terhadap Peran Molekul Adhesi Eritrosit Terinfeksi Plasmodium 
Falciparum Isolat Malang dan Keterlibatan Senyawa Oksigen Reaktif. [Disertasi]. Universitas Brawijaya Malang. 2004.

11. Rosidah A. Efek Pemberian Kombinasi Klorokuin dan $\mathrm{N}$-acetyl cystein terhadap Perubahan Derajat Nekrosis Sel Epitel Tubulus Proksimal Ginjal Mencit Galur Balb/C yang diinfeksi Plasmodium berghei. [Skripsi]. Universitas Brawijaya, Malang. 2004.

12. Staal FJ, Ela SW, Roedeerer M, Anderson MT, and Herzenberg LA. Glutathione Deficiency and Human Immunodeficiency Virus Infection. The Lancet. 1992; 339(8798): 909-912.

13. Treeprasertsuk S, Krudsood S, Tosukhowong T, et al. $\mathrm{N}$-Acetyl Cysteine in Severe Falciparum Malaria in Thailand. The Southeast Asian Journal of Tropical Medicine and Public Health. 2003; 34(1): 37-42.

14. Ker AME, Panzer A, and Viljoen M. The Whip of Falciparum Malaria. The Medicine Journal. 2002; 44(1): 17-18.

15. Viljoen $\mathrm{M}$ and Panzer A. Introduction to Nitric Oxide. The Medicine Journal, 2001; 43(6): 36-38.

16. Clark IA, MM Awburn, Harper CG, Liomba NG, and
Molyneux ME. Introduction of $\mathrm{HO}-1$ in Tissue Macrophages and Monocytes in Fatal Malaria and Sepsis. Malaria Journal. 2003; 2: 41.

17. Burgner D, Rockett $K$, and Kwiatkowski D. Nitric Oxide and Infectious Disease. Archieves of Disease in Childhood. 1999; 81(2): 185-188.

18. Sukarban dan Zunilda. Obat Malaria. Di dalam: Ganiswara (Ed). Farmakologi dan Terapi. Jakarta: Balai Penerbit FKUI; 1999; p. 545-559.

19. Mycek MJ. Farmakologi Ulasan Bergambar. Jakarta: Widya Medika; 2001; p. 128-129.

20. Ghigo D, Aldieri E, Todde $\mathrm{R}$, et al. Chloroquine Stimulates Nitric Oxide Synthesis in Murine, Porcine and Human Endothelial Cells. The Journal of Clinical Investigation 1998; 102(3): 595-605.

21. Halliwel B and Gutteridge JMC. Free Radical in Biology and Medicine. 3rd edition. Oxford: Oxford University Press; 1998; p. 140-148.

22. Watt G, Jongsakul K, and Ruangvirayuth R. A Pilot Study of N-Acetyl Cysteine as Adjuctive Theraphy for Severe Malaria. QJM: An International Journal of Medicine. 2002; 95(5): 285-290. 